\title{
TEKS-TEKS KEISLAMAN DALAM KAJIAN FEMINISME MUSLIM Telaah Metodologis atas Pandangan Feminis Muslim terhadap Penciptaan dan Kepemimpinan Perempuan
}

\author{
Hj. Lift Anis Ma'shumah, M.Ag \\ Fakultas Tarbiyah IAIN Walisongo Semarang
}

\begin{abstract}
Abstrak
Islam diyakini sebagai agama yang rahmatan lil 'alamin, yaitu agama yang menebarkan rahmat bagi alam semesta. Salah satu bentuk dari rahmat tersebut adalah pengakuan Islam terhadap keutuhan kemanusiaan perempuan yang setara dengan lakilaki. Islam tidak memberikan keutamaan kepada jenis kelamin tertentu. Namun ajaran Islam tentang relasi gender yang demikian ideal itu tidak terimplementasikan dengan baik. Praktik masyarakat Islam dalam relasi gender ini masih sangat distortif dan bias, hal ini disebabkan karena pemahaman yang sangat harfiyah terhadap teks-teks agama.
\end{abstract}

Kata Kunci: feminisme, Islam, feminis Muslim, qawwam

\section{A. Pendahuluan}

Kajian keislaman akhir-akhir ini semakin menarik dan bermunculan seiring dengan kehadiran wacana gender dalam studi Islam. Persoalan hak-hak perempuan dan kedudukan perempuan (relasi laki-laki dan perempuan) atau yang biasa disebut isu gender merupakan salah satu isu besar dalam pemikiran Islam kontemporer selain isu-isu yang lain. Isu ini muncul dari keprihatinan yang sangat mendalam atas ketertindasan atau ketimpangan gender yang terjadi di semua aspek kehidupan. Disisi lain gender merupakan sebuah persoalan sosial budaya dan konstruksi sosial yang tentunya tidak semua orang bisa memahami persoalan-persoalan ketidakadilan gender. Persoalan tersebut akan semakin rumit apabila terkait erat dengan doktrin ajaran agama. 
Islam sebagai agama pada hakekatnya terlihat pada aspek nilai-nilai kemanusiaan yang terkandung di dalamnya. Salah satu bentuk dari nilai kemanusiaaan tersebut adalah pengakuan yang tulus terhadap kesamaan dan kesatuan manusia. Kedudukan manusia sebagai Khalifatullah fi al-ardh, merupakan makhluk yang paling mulia dan bermartabat (QS. al-Baqarah, [2]: 30 dan al-Isra'[17]: 70). ${ }^{1}$ Nilai kemanusiaan tersebut secara jelas menggambarkan prinsip dimana Islam tidak membeda-bedakan kedua jenis makhluk yaitu perempuan dan laki-laki, mereka memiliki kedudukan yang sama. Bahkan Islam sangat menjunjung tinggi nilai kemanusiaan, kesamaan dan keadilan tersebut. Konsep ini sangat penting terutama dalam kaitan dengan pemahaman terhadap teks-teks suci keagamaan.

Pemahaman keagamaan umat Islam untuk menyikapi berbagai persoalan, sudah terlanjur menyakini kebenaran teks sebagai sesuatu yang mutlak dan abadi sehingga mengabaikan kenyataan dan pengalaman manusia yang konkret. Mereka berhenti pada makna-makna literalis tanpa menghiraukan konteks ajaran dan bahkan menghiraukan tujuan dasar dalam ajaran Islam itu sendiri yaitu untuk kemaslahatan umat manusia. Itulah yang terjadi dalam pemahaman umat Islam menyangkut relasi gender.

Dalam konteks pemahaman terhadap relasi gender dalam Islam haruslah tetap didasarkan pada sumber ajaran Islam yang utama yaitu alQur'an dan al-Hadits. Namun pemahaman terhadap kedua sember tersebut tidak semata secara tekstual namun juga harus secara kontekstual, baik konteks makro berupa tradisi masyarakat Arab dan kondisi sosialpolitik dan sosial-historis ketika itu maupun konteks mikro dalam wujud asbab an-nuzul ayat dan asbab wurud hadits. Pemaknaan non-literal terhadap teks-teks suci agama dalam al-Qur'an dan al-Hadits mengacu pada tujuan hakiki syari'at yang lazim disebut maqasid al-syari'ah. ${ }^{2}$ Tujuan hakiki

1 Kemuliaan martabat manusia dikarenakan manusia memiliki keunggulan. Menurut Ali Syari'ati, keunggulan manusia bukan terletak pada superioritas rasionalnya namun terletak pada akal dan pengetahuannya.

2 Istilah ini pertama kali diperkenalkan oleh Abu Ishaq al-Syatibi dalam bukunya yang terkenal: al-Muwafaqat fi Usul al-Syari'ah. 
syari'at Islam adalah mewujudkan kemaslahatan manusia melalui perlindungan terhadap lima hak dasar manusia (al-kulliyat al-khamsah), yaitu hak hidup (hifzh an-nafs), hak kebebasan beragama (hifzh al-din), hak beropini dan berkespresi (hifzh al-'aqt), hak reproduksi (hifzh al-nast) dan hak property (hifzh al-mal). Terhadap semua pemahaman keislaman yang tidak kondusif terhadap pemenuhan kelima hak dasar tersebut harus dikaji ulang.

Mengacu pada kelima hak dasar di atas bisa dipahami bahwa sesungguhnya syari'at Islam dibangun untuk kepentingan manusia dan tujuan kemanusiaan yang universal, seperti kemaslahatan, keadilan, kerahmatan dan kebijaksanaan, dan inilah yang menajadi prinsip Islam. Ibnu Rusyd mengatakan bahwa kemaslahatan itu merupakan akar dari berbagai syari'at yang ditetapkan Tuhan. ${ }^{3}$

Islam diyakini sebagai agama yang rahmatan lil 'alamin, yaitu agama yang menebarkan rahmat bagi alam semesta. Salah satu bentuk dari rahmat tersebut adalah pengakuan Islam terhadap keutuhan kemanusiaan perempuan yang setara dengan laki-laki. ${ }^{4}$ Islam tidak memberikan keutamaan kepada jenis kelamin tertentu. Namun ajaran Islam tentang relasi gender yang demikian ideal itu tidak terimplementasikan dengan baik. Praktik masyarakat Islam dalam relasi gender ini masih sangat distortif dan bias, hal ini disebabkan karena pemahaman yang sangat harfiyah terhadap teks-teks agama.

\section{B. Berbagai teks Keislaman yang Bias}

Banyak sekali teks-teks keagamaan yang berkaitan dengan relasi gender yang mengandung bias, ${ }^{5}$ diantaranya:

\footnotetext{
${ }^{3}$ Ibnu Rusyd, Fasl al-Maqal fi Taqrir ma baina al-Syari'at wa al-Hikmah min al-Ittishal aw Wujuh an-Nazhar al-'Agli wa Hudud al-Ta'wil, (Beirut: Dirasah al-Wihdah al-Arabiyah, 1999), h. 125.

${ }^{4}$ Pengertian ini disimpulkan dalam beberapa ayat al-Qur'an, seperti QS. al-Nahl, [16]: 97; QS. al-An'am [6]: 165; QS. al-Mumtahanah [60]: 12.

${ }^{5}$ Siti Musdah Mulia, Islam dan Inspirasi Kesetaraan Gender, (Yogyakarta: Kibar Press, 2007), h. 12-13.
} 


\section{Asal Usul Penciptaan Manusia}

Pemahaman tentang asal usul penciptaan manusia dalam kitab Fiqih menjelaskan bahwa Nabi Adam as. adalah manusia pertama diciptakan oleh Allah SWT, sedangkan istrinya Hawa diciptakan dari tulang rusuk Nabi Adam as. Pemahaman seperti ini mengacu pada pengertian harfiyah al-Qur'an surat al-Nisa' [4]: 1. Pemahaman ini membawa implikasi dalam kehidupan sosial dimana perempuan patut untuk didiskriminasi dan disubordinasikan. Perempuan bukanlah manusia utama namun hanya sebagai pelngkap laki-laki. Konsekuensinya, perempuan tidak boleh berada di depan atau menjadi pemimpin.

\section{Kisah Kejatuhan Adam dan Hawa dari Surga}

Pemahaman tentang hal ini pada umumnya ulama menyampaikan bahwa Nabi Adam jatuh dari surga dikarenakan godaan dari istrinya Hawa yang terpengaruh oleh bisikan setan (QS. al-'A'raf [7]: 20-22). Implikasi dari pemahaman yang demikian adalah membawa pandangan strereotip bahwa perempuan merupakan seorang penggoda.

\section{Kepemimpinan Perempuan}

Sifat gender seorang perempuan yang lemah, lembut, halus perasaan, pendek akal, membawa pemahaman bahwa perempuan tidak layak menjadi seorang pemimpin karena dikhawatirkan tidak bisa membuat keputusan. Apalagi dalam sebuah hadits yang menyatakan bahwa "perempuan itu lemah akal dan agamanya" (HR. Bukhari dari Saidah ibn Abi Maryam), dan juga ada hadits lain yang menyatakan bahwa "celakalah suatu kaum yang mempercayakan kepemimpinannya kepada perempuan" (HR. Bukhari dari Abu Bakrah). Kedua hadits tersebut diperkuat pula dengan ayat al-Qur'an yang menjelaskan bahwa laki-laki itu pemimpin bagi perempuan (QS. al-Nisa' [4]: 34).

Dari ketiga contoh pemahaman terhadap teks keagamaan di atas, menguatkan pandangan bahwa posisi dan peran perempuan lebih rendah daripada laki-laki. Pemahaman yang bias gender tersebut justru banyak 
yang terjadi dan justru dipraktikkan oleh masyarakat Islam. Akibatnya perempuan mengalami ketimpangan atau ketidakadilan gender. ${ }^{6}$ Sebagaimana disebutkan bahwa ketimpangan gender terjadi karena budaya patriarkhi dan pemahaman terhadap ajaran agama yang bias gender. ${ }^{7}$

Ajaran Islam terpolakan ke dalam dua bentuk, yaitu ajaran dasar dan ajaran non-dasar. Ajaran dasar adalah ajaran yang termaktub dalam alQur'an dan Sunnah mutawatir yang diyakini datang dari Allah dan RasulNya. Ajaran dasar ini bersifat absolut, abadi dan tidak berubah. Sedangkan ajaran non-dasar adalah ajaran berupa hasil ijtihad manusia dalam bentuk tafsir, interpretasi atau pemikiran ulama yang menjelaskan tentang ajaran dasar dan implementasinya dalam kehidupan nyata. Ajaran non-dasar ini bersifat ijtihadi, relatif dan tidak abadi. Sebagian besar ajaran Islam yang menyinggung soal relasi gender termasuk dalam ajaran kedua. Oleh karenanya perlu pembacaan ulang dan upaya dekonstruksi atas hasil ijtihad atau penafsiran lama yang dinilai bias gender dan bias nilai-nilai patriarki. Penafsiran baru atas teks-teks keagamaan mendesak dilakukan untuk menemukan kembali pesan-pesan keIslaman yang hakiki dan universal, seperti pesan persamaan, persaudaraan, kebebasan, kesetaraan dan keadilan, termasuk di dalamnya keadilan dan kesetaraan gender.

\section{Kedudukan Perempuan dalam Hukum Islam}

Islam menempatkan kedudukan perempuan pada proporsinya dengan mengakui kemanusiaan perempuan dan mengikis habis kegelapan

\footnotetext{
${ }^{6}$ Ketimpangan gender merupakan kondisi dimana perempuan tidak mendapatkan akses, partisipasi, control dan manfaat yang sama antara laki-laki dan perempuan. Berbagai bentuk ketimpangan gender, misalnya diskriminasi, subordinasi, stereotip, kekerasan (violence) dan beban ganda (double burden). Lihat: Mansour Fakih, Analisis Gender dan Transformasi Sosial, (Yogyakarta: Pustaka Pelajar, 1996), h. 13-23.

${ }^{7}$ Paling tidak ada tiga alasan yang menyebabkan munculnya pemahaman keagamaan yang bias, yaitu pertama, umumnya umat Islam lebih banyak memahami agama secara dogmatis bukan berdasarkan penalaran yang kritis. Kedua, umumnya masyarakat Islam memperoleh pengetahuan keagamaan melalui ceramah para ulama -yang umumnya sangat bias gender. Ketiga, pemahaman banyak mengacu pada pemahaman tekstual terhadap kitab suci bukan pemahaman kontekstual.
} 
yang dialami perempuan sepanjang sejarah serta menjamin hak-hak perempuan. Untuk menjelaskan kedudukan perempuan dalam hukum Islam, dasar hukum yang harus dipegangi adalah kedua sumber utama hukum Islam, yaitu al-Qur'an dan Sunnah (hadis). Dari dua sumber inilah diperoleh prinsip-prinsip yang pasti untuk melihat kedudukan perempuan dalam Islam. Namun, harus dimaklumi bahwa prinsip-prinsip yang sudah digariskan oleh al-Qur'an dan Sunnah terkadang dipraktikkan berbeda oleh umat Islam dalam kehidupan sehari-hari. Bahkan harus disadari pula bahwa ayat-ayat al-Qur'an dan hadis-hadis Nabi SAW yang sebenarnya menyuarakan masalah keadilan dan persamaan sering dipahami yang sebaliknya, sehingga di kalangan pemikir Islam (ulama) timbul perbedaan pendapat dalam berbagai permasalahan Islam, termasuk hukum Islam.

Al-Qur'an dengan tegas menyebutkan bahwa kaum laki-laki dan kaum perempuan diciptakan dari nafs (jiwa) yang sama, dan bahwa orang laki-laki dan perempuan Muslim adalah masing-masing sebagai pelindung dan sahabat bagi yang lainnya. Keduanya juga memiliki tugas yang sama dan kesempatan untuk memeroleh rahmat dari Allah (QS. al-Taubah [9]: 71). al-Qur'an selalu menekankan logika yang berasal dari Allah, ketika berulang-ulang menyebutkan bahwa laki-laki dan perempuan diciptakan dari nafs yang sama (QS. al-Nisa' [4]: 1, al-An'am [6]: 98, al-A'raf (7): 189, Luqmān (31): 28, dan al-Zumar (39): 6). Dalam al-Qur'an tidak terdapat satu penjelasan sedikit pun seperti dalam kitab-kitab suci lainnya bahwa perempuan diciptakan dari suatu bahan yang lebih rendah dari bahan untuk laki-laki, bahwa status perempuan adalah parasit dan rendah, atau bahwa Hawa diciptakan dari salah satu tulang rusuk kiri Adam. Di samping itu, dalam al-Qur'an tidak ada satu pandangan pun yang meremehkan perempuan berkenaan dengan watak dan struktur bawaannya. al-Qur'an membersihkan perempuan dari tuduhan sebagai sumber godaan dan dosa seperti yang dijelaskan dalam kitab-kitab suci lainnya. ${ }^{8}$

${ }^{8}$ Murteza Mutahhari, Perempuan dan Hak-haknya dalam Islam. Alih bahasa oleh M. Hashem dari “The Rights of Women in Islam.” (Bandung: Pustaka, 1985), h. 96-97. 
Studi yang dilakukan Nasaruddin Umar ${ }^{9}$ terhadap al-Qur'an menunjukkan adanya kesetaraan gender. Dia menemukan lima variabel yang mendukung pendapatnya, yakni: (1) Laki-laki dan perempuan sama-sama sebagai hamba. Hal ini bisa dilihat misalnya dalam QS. al-Hujurat [49]: 13 dan al-Nahl [16]: 97; (2) Laki-laki dan perempuan sebagai khalifah di bumi. Hal ini terlihat dalam QS. al-Baqarah [2]: 30 dan al-An'am [6]: 165; (3) Laki-laki dan perempuan menerima perjanjian primordial seperti terlihat dalam QS. al-A'raf [7]: 172; (4) Adam dan Hawa terlibat secara aktif dalam drama kosmis. Kejelasan ini terlihat dalam QS. al-Baqarah [2]: 35 dan 187, al-A'raf [7]: 20, 22, dan 23; dan (5) Laki-laki dan perempuan berpotensi meraih prestasi seperti yang terlihat dalam QS. Ali 'Imran [3]: 195, al-Nisa' [4]: 124, al-Nahl [16]: 97, dan al-Mu'min [40]: 40.

Beberapa ayat di atas telah membawa misi keadilan dan kesetaraan. Namun dalam memahami ayat-ayat tersebut terkadang para penafsir mengambil keputusan yang berbeda hanya karena adanya ayat yang bisa diarahkan sesuai dengan penafsirannya dan juga karena didukung oleh budaya patrilineal yang kental di kalangan masyarakat Muslim. Adanya hadis-hadis Nabi yang misoginis (merendahkan perempuan) lebih memperkuat keyakinan penafsir untuk memegangi pendapatnya. Di sinilah muncul tafsir-tafsir yang banyak memposisikan perempuan dalam posisi yang inferior.

Dalam kurun waktu berabad-abad lamanya, penafsiran yang merendahkan perempuan mendominasi opini dan keyakinan umat Islam di belahan bumi ini. Munculnya feminisme di Barat memberikan inspirasi yang sangat berharga kepada sebagian kecil umat Islam (para penafsir) akan pentingnya melakukan reinterpretasi dan reformulasi fikih (pemahaman hukum) perempuan. Dengan mendasarkan kepada ayat-ayat alQur'an yang membawa misi keadilan, persamaan, dan kesetaraan, mereka berusaha mencari akar masalah mengapa muncul penafsiran yang tidak adil dalam memberikan status terhadap laki-laki dan perempuan

9 Nasaruddin Umar, Argumen Kesetaraan Jender: Perspektif al-Qur'an, Jakarta: Paramadina, 1999), h. 248-269. 
(gender). Mereka melakukan penelusuran terhadap hadis-hadis yang menjadi "biang" terjadinya ketidakadilan tersebut dan menfsirkan dengan melihat konteks (asbabul wurud) hadis tersebut. Mereka inilah yang dikenal dengan kaum feminis Muslim.

Tulisan berikut akan dipaparkan pemmembacaaan terhadap teks-teks keislaman khususnya tentang relasi laki-laki dan perempuan telah dibaca oleh para feminis muslim. Pembahasan ini dimaksudkan untuk memberikan sumbangan bagi pemikiran Islam khususnya dalam perspekif gender. Dalam makalah ini batasi pada pemikiran Riffat Hasan, Amina Wadud Muhsin, Fatimah Mernissi dan Hussein Muhammad. Namun pembahasan sebelumnya akan dikemukakan sedikit tentang feminisme sebagai gerakan kesetaraan.

\section{Feminisme sebagai Gerakan Kesetaraan (Feminisme Barat vs Feminisme Islam)}

Gerakan Feminisme lahir dari sebuah ide yang diantaranya berupaya melakukan pembongkaran terhadap ideologi penindasan atas nama gender, pencarian akar ketertindasan perempuan, sampai upaya penciptaan pembebasan perempuan secara sejati. Feminisme ${ }^{10}$ adalah basis teori dari gerakan pembebasan perempuan. Pada awalnya gerakan ini memang diperlukan pada masa itu (masa Revolusi Amerika tahun 1776 dan Revolusi Perancis tanuh 1792), dimana ada masa-masa pemasungan terhadap kebebasan perempuan. Sejarah dunia menunjukkan bahwa secara umum kaum perempuan (feminin) merasa dirugikan dalam semua bidang dan dinomor duakan oleh kaum laki-laki (maskulin) khususnya dalam masyarakat yang patriakhis sifatnya. Dalam bidang-bidang sosial, pekerjaan, pendidikan, dan lebih-lebih politik hak-hak kaum ini biasanya

${ }^{10}$ Kata feminisme dicetuskan pertama kali oleh aktivis sosialis utopis, Charles Fourier pada tahun 1837. Istilah feminism berasal dari bahasa Latin (femina = woman), yang berarti memiliki sifat-sifat wanita. Pergerakan yang berpusat di Eropa ini berpindah ke Amerika dan berkembang pesat sejak publikasi John Stuart Mill, "Perempuan sebagai Subjek" (The Subjection of Women) pada tahun (1869). Perjuangan mereka menandai kelahiran feminisme Gelombang Pertama 
memang lebih inferior ketimbang apa yang dapat dinikmati oleh laki-laki, apalagi masyarakat tradisional yang berorientasi agraris cenderung menempatkan kaum laki-laki di depan, di luar rumah dan kaum perempuan di rumah. Dengan kondisi yang menggambarkan ketidakadilan gender tersebut, para feminis berusaha untuk menganalisis sebab-sebab terjadinya penindasan terhadap perempuan, berusaha mendapatkan kebebasan bagi perempuan, dan berusaha memperoleh kesetaraan sosial dengan laki-laki dalam segala bidang. ${ }^{11}$ Dalam usahanya itu gerakan feminism diwarnai oleh penolakannya terhadap sistem patriarki dengan cara meruntuhkan struktur patrirki dalam masyarakat. ${ }^{12}$ Situasi ini mulai mengalami perubahan ketika datangnya era Liberalisme di Eropa dan terjadinya Revolusi Perancis di abad ke-18 yang gemanya kemudian melanda Amerika Serikat dan ke seluruh dunia.

Pada tahun 1759-1797, feminis mulai menggunakan kata-kata "hak." Saat itu, Mary wollstonecraft, feminis pertama yang mengatakan adanya pembodohan terhadap perempuan yang disebabkan tradisi masyarakat yang menjadikan perempuan sebagai makhluk yang tersubordinasi. Tahun 1970-1980an wacana feminisme bermunculan di Amerika Latin, Asia, dan di negara-negara Dunia ketiga pada umumnya. Tahun 19601970an, feminis mulai membawa perubahan sosial yang luar biasa di dunia Barat dimana lahirnya undang-undang yang menguntungkan perempuan dan konsep patriarki yang mulai mengemuka. Pada abad ke-20 (1949) lahir karya Simone de Beauvoir "Le Deuxieme Sexe", dan akhirnya ditemukan istilah kesetaraan.

Sejak adanya gerakan feminisme telah muncul berbagai teori feminisme yang masing-masing memiliki landasan dan pola pikir yang berbeda. Berikut ini akan diuraikaan garis besar dari beberapa teori feminisme, yaitu feminism liberal, feminisme sosialis dan feminisme radikal.

\footnotetext{
${ }^{11}$ Margeret L. Andersen, Thingking About Women: Perspectives on Sex and Gender, (New York: McMillan Pub. Co., 1988), h. 84-86.

${ }^{12}$ Ratna Megawangi, “Perkembangan Teori Feminisme Masa Kini dan Mendatang serta Kaitannya dengan Pemikiran Keislaman', dalam Mansour Fakih, dkk., Membincang Feminisme ..., h. 209-229.
} 


\section{Feminisme Liberal}

Teori feminis ini berakar pada pandangan filsafat liberalisme yang memiliki konsep individu dan penekanan pada penalaran sebagai dasar perubahan sosial. ${ }^{13}$ Dalam pandangan ini kebebasan merupakan hak setiap individu sehingga ia harus diberikan kebebasan untuk memilih. Ketidaksetaraan dalam masyarakat terjadi karena adanya pelanggaran terhadap kebebasan individu. Ketimpangan peran gender yang melemahkan perempuan dalam pandangan teori ini disebabkan karena proses belajar melalui sosialisasi peran atas dasar seks. Ketidaksetaraan juga muncul melalui stereotip yang dianggap oleh laki-laki ataupun perempuan sebagai sifat yang harus dilanggengkan melalui keluarga, sekolah, media massa dan agen-agen sosial lainnya. ${ }^{14}$ Oleh karenanya kesetaraan dapat dicapai melalui kebijaksanaan peraturan atau proses pendidikan.

Dalam perkembangannya, feminisme liberal dikenal sebagai aliran utama feminisme, secara khusus di Amerika dan dianggap sebagai satusatunya aliran feminisme. Perhatian utama dari feminisme ini adalah persamaan hak (equal rights) secara luas bagi petrempuan mengembangkan nilai-nilai kebebasan liberal, persamaan dan keadilan melalui reformasi hukum dan sosial. ${ }^{15}$ Salah satu tokoh feminism liberal ini adalah Mary Wolstonecraff yang dalam bukunya A Vindication of the Right of Women (1792) menganjurkan kesamaan hukum dan kesempatan yang luas dalam segenap aspek kehidupan kepada perempuan.

\section{Feminisme Sosialis}

Berbeda dengan feminis liberalis, feminis sosialis memiliki pandangan yang radikal tentang terjadinya penindasan terhadap kaum perempuan. Menurut teori sosialis, penindasan tersebut berakar pada sistem kapitalisme dan patriarkhi sekaligus secara interaktif. Sebagaimana Marxis klasik,

\footnotetext{
${ }^{13}$ Margaret L. Anderson, Thingking About Women ...., h. 296.

${ }^{14}$ R.W. Connel, Gender and power Society, The Person and Sexual Politics (Stanford: Standford University Press, 1987), h. 34. h. 182.

${ }^{15}$ Lisa Tuttle, Encyclopedia of Feminism, (New York: Facts On File Publications, 1986),
} 
femnis sosialis juga memandang bahwa sistem kelas dan hubungan ekonomi kapitalis telah mendorong munculnya penindasan terhadap perempuan. ${ }^{16}$ Dalam pandangan kapitalisme, perempuan dianggap sebagai milik laki-laki dan demi kepentingan mendapatkan keuntungan diperlukan eksploitasi terhadap perempuan. Feminisme sosialis bertujuan mengadakan restrukturisasi masyarakat. Restrukturisasi masyarakat yang berarti meruntuhkan sistem sosial yang ada. Mereka berusaha menghapuskan sistem kelas dan gender yang ada dalam masyarakat, sistem sosial yang tergambar dalam patriarki kapitalis.

Feminisme sosialis mengajurkan agar perempuan sadar bahwa mereka adalah kelas yang tidak diuntungkan. Proses penyadaran ini adalah usaha untuk membangkitkan rasa emosi para perempuan agar bangkit untuk merubah keadaanya. Secara berkelompok perempuan diharapkan untuk mengadakan konflik langsung dengan kelompok dominan (laki-laki). Semakin tinggi tingkat konflik antara kelas perempuan dan kelas dominan, diharapkan meruntuhkan sistem patriarki. Premis ini berasal dari konsep-dialektis yang dikembangkan oleh Hegel yang diacu oleh Marx. ${ }^{17}$

\section{Feminisme Radikal}

Berbeda dari pandangan feminisme sosialis, menurut feminis radikal, penindasan terhadap perempuan terjadi karena semata-mata hubungan sosial yang patriarkis. ${ }^{18}$ Mereka memandang bahwa patriarki merupakan sistem kekuasaan yang seksis yang menganggap bahwa laki-laki memiliki superioritas atas perempuan. Pandangan tersebut berakar pada pembagian kerja atas dasar seks yang terjadi dalam masyarakat.

Sistem patriarki dalam pandangan teori ini mendapat legitimasi dalam lembaga keluarga yang memberikan tempat yang subur bagi ber-

${ }^{16}$ Siti Hidayati Amal, "Beberapa Perspektif Feminis dalam Menganalisa Permasalahan Wanita", dalam T.O. Ihromi (penyunting), Kajian Wanita dalam Pembangunan (Jakarta: yayasan Obor Indonesia, 1995), h. 104-105.

${ }^{17}$ Mansour Fakih (et.al), Membincang Feminisme ...., h. 226.

${ }^{18}$ Margaret L. Anderson, Thingking About Women ...., h. 320. 
kembangnya dominasi laki-laki yang menyebabkan terjadinya penindasan terhadap perempuan. Faminis radikal ini lebih menyerang institusi keluarga. Keluarga dianggap sebagai institusi yang melegitimasi dominasi laki-laki atas perempuan. Karena pandangan yang demikian, feminis radikal cenderung membenci laki-laki sebagai individu sehingga kebanyakan mereka hidup sebagai lesbian. ${ }^{19}$ Dengan demikian, menurut pandangan feminis radikal, hanya dengan menghilangkan sistem patriarkhilah pembebasan perempuan dari penindasan dalam masyarakat akan berhasil.

\section{Feminisme Islam}

Tidak dapat dipungkiri dengan munculnya gerakan feminisme di Barat berpengaruh juga terhadap dunia Timur termasuk Negara-negara yang berpenduduk muslim yang secara garis besar menganut sistem patriarki. Sehingga tidak mengherankan jika di kalangan Islam sendiri telah lahir para feminis muslim yang mempunyai perhatian terhadap kondisi masyarakat Islam terutama nasib kaum perempuan.

Jantung diskursus gerakan feminis Islam adalah isu reinterpretasi progresif terhadap al-Qur'an, seperti sedang dikaji antara lain oleh Riffat Hasan dan Asghar Ali Enginer. Salah satu kritik utama feminis Islam terhadap feminis Barat adalah kecenderungannya kepada sekularisme. Menurut teologi feminisme Islam, konsep hak-hak asasi manusia yang tidak berlandaskan visi transendental merupakan hal yang tragis. Karenanya, mereka berpandangan gerakan perempuan Islam harus berpegang pada paradigma agama supaya tidak menjadi sekular. Fatima Mernissi (1988) dan Issa J. Boullata (1989), misalnya, menegaskan bahwa perempuan Islam harus mengembangkan program-program feminisnya sendiri dengan menggunakan kerangka acuan yang Islami.

${ }^{19}$ Ratna Megawangi, “Perkembangan Teori Feminisme Masa Kini dan Mendatang serta Kaitannya dengan Pemikiran Keislaman", dalam Mansour Fakih dkk., Membincang Feminisme ..., h. 226. 
Ada tiga model utama ${ }^{20}$ yang ditempuh para feminis muslim untuk menyuarakan aspirasinya, yaitu pertama, melalui karya-karya tulis yang tertuang dalam bentuk puisi, cerpen, buku, dll. Kedua, adalah gerakan nyata dalam kehidupan sehari-hari dan ketiga, gerakan-gerakan yang lebih terorganisir, yang bergerak di bidang politik dan public yang beridentitas feminis. Cara lain yang ditempuh para feminis muslim adalah melalui reinterpretasi berbagai ajaran Islam yang merugikan perempuan. Mereka menganggap bahwa kondisi yang menimpa kaum muslimah adalah akibat dari interpretasi ajaran Islam yang didominasi sistem patriarki. Beberapa feminis dimaksud dan besar pengaruhnya di Indonesia ini adalah Riffat Hasan (Pakistan), Amina wadud (Malaysia), Fatima Mernissi (Maroko) dan Asghar Ali Enginer (India). Sederatan nama feminis muslim Indonesia, diantaranya Masdar F. Mas'udi, Mansour Fakih, Ratna Megawangi, dll.

Sebagaimana feminisme pada umumnya, feminisme Islam bukan merupakan pemikiran teoritis dan gerakan yang seragam. ${ }^{21}$ Meskipun demikian, gerakan atau teori feminisme mereka muncul dari kesadaran yang sama, yakni keprihatinan terhadap kenyataan bahwa perempuan dalam struktur sosial masyarakat muslim masih belum memperoleh kedudukan yang setara dengan laki-laki. Mereka berpandangan bahwa keadaan yang memperihatinkan tersebut tidak disebabkan oleh ajaran dasar Islam yang menempatkan perempuan di bawah laki-laki dalam struktur sosial, tetapi oleh "bias laki-laki" dalam memahami sumber ajaran Islam yang aplikasinya dalam kehidupan masyarakat membentuk tradisi Islam. ${ }^{22}$ Pemahaman yang bias tersebut telah menyimpang dari

${ }^{20}$ Mundir, Perempuan dalam al-Qur'an (Studi Tafsir al-Manar), (Semarang: Walisongo Press, 2010, h. 58)

${ }^{21}$ Budhy Munawar Rahman, "Islam dan Feminisme: Dari Sentralisme kepada Kesetaraan", dalam Mansour Fakih dkk, Membincang Feminisme ..., h. 181.

${ }^{22}$ Meskipun sumber utama pembentukan tradisi Islam adalah al Qur'an al Hadis, sumber-sumber lain seperti fikih dan syari'ah juga memberikan sumbangan yang berarti dalam membangun ajaran Islam. Namun, sumber-sumber tersebut tidak membentuk bangunan yang koheren dan konsisten yang dijabarkan menjadi norma-norma Islam yang disepakati bersama. Penafsiran terhadap sumber-sumber inilah yang dalam perkembangannya melahirkan pemahaman tentang ketidaksetaraan gender dalam masyarakat muslim. Baca: Mernissi dan Rifat Hasan, Setara di Hadapan Allah: Relasi 
semangat dasar al-Qur'an sehingga memiliki dampak yang nyata dalam memberikan hak-hak kepada perempuan dalam kehidupan masyarakat. ${ }^{23}$ Oleh karena itu, dalam perjuangan membebaskan perempuan dan ketidakadilan gender, para feminis muslim berusaha membongkar historisitas akar permasalahan yang menyebabkan ketidakadilan, dan selanjutnya mengembangkan pemahaman baru tentang hubungan gender tersebut berdasarkan sumber ajaran Islam yaitu al-Qur'an dan al-Hadits. ${ }^{24}$ Dalam bentuk konkritnya usaha ini dilakukan dengan cara menafsirkan kembali teks-teks tersebut dengan mempertimbangkan konteks kesejarahan teks itu sendiri dan prinsip dasar yaitu keadilan.

\section{E. Pandangan Feminis Muslim terhadap Penciptaan dan Kepemimpinan Perempuan}

Pembahasan berikutnya dalam makalah ini akan disajikan dua tema dalam perspektif feminis muslim, yaitu pertama, tentang penciptaan perempuan dalam padangan Riffat Hasan dan Amina Wadud Muhsin, kedua, kepemimpinan perempuan dalam pandangan Fatima Mernissi dan Hussein Muhammad.

\section{Penciptaan Perempuan dalam Pandangan Riffat Hasan dan Amina Wadud Muhsin}

Isu utama yang diperbincangkan oleh feminis muslim adalah penciptaan perempuan. Menurut mereka pemahaman tentang penciptaan perempuan dan laki-laki adalah tidak lepas dari penafsiran ulama terhadap literature-literatur keagamaan yang bias laki-laki. Para ulama menganggap Hawa (istri Adam) diciptakan dari tulang rusuk Adam. Karena adanya anggapan semacam itu, maka muncul pemahaman bahwa perempuan

Perempuan dalam Tradisi Islam Pasca Patriarki (terj. Tim LSPPA), (Yogyakarta: LSPPA, 1995), h. 67-108.

${ }^{23}$ Asghar Ali Enginer, Hak-Hak Perempuan dalam Islam (diterjemahkan dari The Origin and Developmnet of Islam oleh Farid Wajdi dan Cici Farcha Assegaf), (Yogyakarta: Yayasan Banteng Budaya, 1994), h. 271.

${ }^{24}$ Yunahar Ilyas, Feminisme dalam Kajian Tafsir al-Qur'an Klasik dan Kontemporer, (Yogyakarta: Pustaka Pelajar, 1997), h. 53-55. 
diciptakan dari laki-laki. Salah satu sumber keagamaan yang dijadikan landasan pandangan ini adalah al-Qur'an surat al-Nisa' ayat 1:

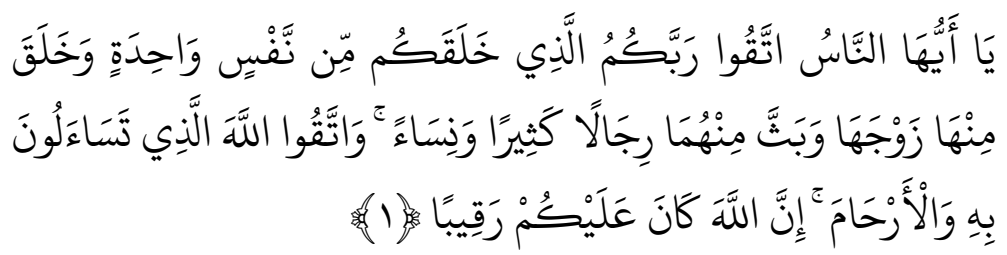

"Hai sekalian manusia, bertakwalah kepada Tuhan-mu yang Telah menciptakan kamu dari seorang diri, dan dari padanya. Allah menciptakan isterinya; dan dari pada keduanya Allah memperkembangbiakkan laki-laki dan perempuan yang banyak. dan bertakwalah kepada Allah yang dengan (mempergunakan) nama-Nya kamu saling meminta satu sama lain, dan (peliharalah) hubungan silaturrahim. Sesungguhnya Allah selalu menjaga dan mengawasi kamu."

Para mufassir klasik ${ }^{25}$ menafsirkan kata nafs dengan adam. Dari pandangan bahwa yang dimaksud dengan nafs adalah Adam, maka dipahami bahwa kata zaujaha secara harfiah adalah "pasangan", yang dimaksudkan sebagai istri Adam adalah Hawa. Oleh karena pasangan itu dipahami berasal dari nafs yang berarti Adam, maka mereka memahami bahwa istri Adam (perempuan) diciptakan dar Adam (laki-laki) sendiri.

Para feminis muslim tidak sependapat dengan penafsiran yang dikemukakan oleh Ibn Kasir maupun al-Zamakhsyari di atas. Riffat Hasan, mengatakan bahwa perempuan (Hawa) tidaklah diciptakan dari

${ }^{25}$ Ibnu Kasir dalam kitab Tafsir al-Qur'an al-Azhim mengatakan bahwa yang dimaksud dengan nafs wahidah adalah Adam dan zaujaha adalah Hawa yang diciptakan dari tulang rusuk Adam yang kiri. Dalam hal ini Ibnu Kasir mengemukakan sebuah hadits yang menceritakan tentang penciptaan perempuan, yaitu "sesungguhnya perempuan diciptakan dari tulang rusuk dan bagian tulang rusuk yang paling kokoh adalah yang paling atas. Jika kamu ingin meluruskannya maka akan patahlah ia, dan jika kamu ingin memperoleh manfaat, maka lakukanlah. Sementara ia tetap memiliki kebengkokan." Lihat: Ibn Kasir, Abu al-Fida' Isma'il bin 'Umar bin Kasir bin Dau', al-Qur'an al-Karim, Jil. 1, (Beirut: Dar al-Ma' rifat, 1976) h. 448. Sementara al-Zamakhsyari dalam kitabnya al-Kasysyaf mengatakan bahwa Allah menciptakan manusia dari asal yang satu yaitu Adam dan menciptakan istrinya, Hawa dari diri Adam itu sendiri. Akan tetapi al-Zamakhsyari tidak mengemukakan sumber rujukan yang mendukung pendapatnya tersebut sebagaimana yang dilakukan Ibn Kasir. Lihat: al-Zamakhsyari, Abu al-Qasim Jarullah Mahmud ibn 'Umar, al-Kasysyaf 'an Haqa'iq at-Tanzil wa 'Uyun al-Aqa'il fi Wujuh al-Tanwil, Jil. 1, (Beirut: Dar al-Fikr, 1977), h. 492. 
laki-laki (Adam). Menurutnya, sikap dan pandangan umat muslim bahwa Adam adalah ciptaan Tuhan yang utama dan Hawa diciptakan dari tulang rusuk Adam, berasal dari Injil. Riffat Hasan mengutip empat rujukan tentang penciptaan perempuan dalam Genesis. ${ }^{26}$ Dalam kajian terhadap teks-teks genesis tersebut didapati bahwa dalam bahasa Ibrani, istilah Adam berasal dari kata adamah yang berarti tanah. Oleh karena itu tidak dapat dipahami kalau Hawa diciptakan dari diri Adam, karena Adam adalah istilah dalam bahasa Ibrani yang berarti tanah. ${ }^{27}$

Secara khusus, Riffat Hasan menjelaskan bahwa kata nafs bukan merujuk kepada Adam karena kata tersebut bersifat netral,bisa berarti lakilaki dan bisa perempuan, begitu juga kata zauj tidak berarti perempuan karena secara bahasa kata zauj yang berarti perempuan hanya dikenal di kalangan masyarakat Hijaz sementara di daerah lain digunakan kata zaujah. ${ }^{28}$ Dalam hal penciptaan perempuan ini Riffat berkesimpulan bahwa Adam dan Hawa diciptakan dari substansi dan cara yang sama, tidak ada perbedaan di antara keduanya. Menurutnya, hadits-hadits yang menyatakan bahwa Hawa diciptakan dari tulang rusuk Adam harus ditolak karena bertentangan dengan al-Qur'an.

Amina Wadud Muhsin, juga membrikan pandangannya dalam hal penciptaan perempuan. Ia membahas surat al-Nisa' ayat 1 di atas dengan melihat komposisi bahasa dan teks-teks kata perkata. Ia mengatakan bahwa al-Qur'an tidak menjelaskan bahwa Allah menciptakan manusia dari diri laki-laki ataupun yang menunjukkan bahwa asal-usul manusia adalah Adam. Hal itu dilihat dari kata nafs yang berbentuk muannas. Secara konseptual kata nafs tersebut mengandung makna netral, bisa menunjuk kepada laki-laki dan juga bisa menunjuk kepada perempuan. ${ }^{29}$

${ }^{26}$ Terdapat empat rujukan tentang penciptaan perempuan dalam Genesis 1: 26-27, abad ke 25 SM, tradisi kependetaan; 2. Genesis 2: 7 abad ke 10 SM, tradisi kerahiban; 3. Genesis 2: 18-24, abad ke $10 \mathrm{SM}$, tradisi kerahiban; 4. Genesis 5: 1-2 SM, tradisi kependetaan.

${ }^{27}$ Fatima Mernissi dan Riffat Hasan, Setara di Hadapan Allah, Relasi Laki-laki dan Perempuan dalam Tradisi Islam Pasca Patriarki, terj. Team LSPPA (Yogyakarta: Media Gama Offset, 1995), h. 45.

${ }^{28}$ Fatima Mernissi dan Riffat, Setara ..., h. 48.

${ }^{29}$ Amina Wadud Muhsin, Wanita di Dalam al Qur'an, terj. Yaziar Radianti (Bandung: Pustaka, 1994, h. 25 
Para pemikir feminis Muslim tersebut yang berusaha melakukan dekonstruksi terhadap pemahaman para ulama mengenai perempuan yang menempatkan perempuan pada posisi yang inferior dan laki-laki pada posisi yang superior. Beberapa feminis muslim telah mengkaji ulang teks-teks keagamaan, khususnya al-Qur'an, yang berkaitan dengan hubungan gender. Sebagaimana yang dilakukan oleh Amina Wadud Muhsin, feminis Muslim dari Malaysia, telah berpendapat bahwa penafsiran ulang terhadap ayat-ayat al-Qur'an diperlukan dalam rangka untuk menjaga relevansinya dengan kehidupan manusia. ${ }^{30} \mathrm{Hal}$ ini karena kajian-kajian tentang perempuan yang selama ini dilakukan, yang lebih mendasarkan pada teks-teks hasil pemahaman terhadap al-Qur'an daripada mengkaji al-Qur'an sendiri secara mendalam telah menghasilkan kesenjangan antara isi harfiah ayat dan maksud yang terkadung di dalamnya. Hal serupa juga dilakukan oleh Riffat Hasan, feminis Pakistan juga berusaha mengkaji kembali ayat-ayat al-Qur'an yang terkait dengan perempuan. Kajian dilakukan karena terjadi kekeliruan dan bias laki-laki dalam penafsiran sehingga hasilnya menyudutkan wanita pada kedudukan yang lebih rendah daripada laki-laki sebagaimana yang dipahami selama ini. ${ }^{31}$

\section{Kepemimpinan Perempuan dalam Pandangan Fatima Mernissi dan Hussein Muhammad}

Al-Qur'an telah memberikan hak kepada perempuan sebagaimana hak yang diberikan kepada laki-laki, satu diantaranya adalah masalah kepemimpinan. Sebagaimana disebutkan dalam surat al-Taubah ayat 71:

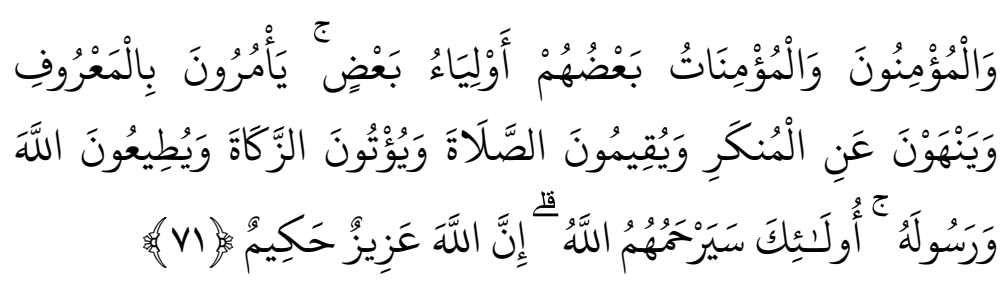

\footnotetext{
${ }^{30}$ Amina Wadud Muhsin, Wanita di Dalam al Qur'an, h. 21.

${ }^{31}$ Fatima Mernissi dan Riffat, Setara ..., h. 42
} 
"Dan orang-orang yang beriman, lelaki dan perempuan, sebagian mereka (adalah) menjadi penolong bagi sebagian yang lain. mereka menyuruh (mengerjakan) yang ma'ruf, mencegah dari yang munkar, mendirikan shalat, menunaikan zakat dan mereka taat pada Allah dan Rasul-Nya. mereka itu akan diberi rahmat oleh Allah; Sesungguhnya Allah Maha Perkasa lagi Maha Bijaksana."

Dalam ayat tersebut, Allah SWT menggunakan kata "awlia" (pemimpin), kata itu bukan hanya ditujukan kepada laki-laki saja tetpai untuk keduanya secara bersama-sama. Berdasarkan ayat tersebut, alQur'an tidak melarang perempuan memasuki wilayah dan berbagai profesi termasuk menjadi seorang pemimpin. Kondisi ini banyak dibuktikan dalam sejarah baik di Indonesi maupun negara Islam. Sebenarnya di Indonesia, kesetaraan gender sudah sangat baik, lihat saja Megawati, beliau seorang perempuan yang menjadi Presiden, sebuah sukses dalam peraihan karir yang paling tinggi di negeri ini. Ada Rini Suwandi seorang professional handal yang menjabat sebagai menteri Perdagangan. Sangat mengherankan bahwa kaum feminis Indonesia tidak merasa terwakili oleh prestasi yang diraih mereka ini. Dilain sisi ada banyak sekali wanita karir di Indonesia yang merangkap menjadi ibu tetapi sukses dalam pekerjaannya. Profil-profil tersebut sudah menggambarkan bahwa perempuan mempunyai andil hebat dalam politik dan perekonomian Negara Indonesia.

Di negara Islam pun kita menjumpai banyak perempuan yang memegang kendali politik tertinggi contohnya Benazir Butto pernah menjabat sebagai Perdana Meteri di Pakistan, Shirin Ebadi perempuan Iran dengan kepribadian luar biasa memenangkan hadiah Nobel 2003. Chandrika Bandaranaike Kumaratunga Presiden Srilanka. Dua perempuan pintar di Philipina Cory Aquino \& Gloria Arroyo. Di belahan dunia lain juga kita kenal Margareth Tacher, Madeleine Albright, dan Madonna perempuan genius dengan kepribadian yang kontraversial dan sangat sukses.

Hanya saja ulama berbeda pendapat dalam memberikan hukum boleh tidaknya perempuan menjadi seorang pemimpin. Kebanyakan 
jumhur ulama melarang perempuan menjadi pemimpin berdasarkan alQur'an surat al-Nisa' ayat 34:

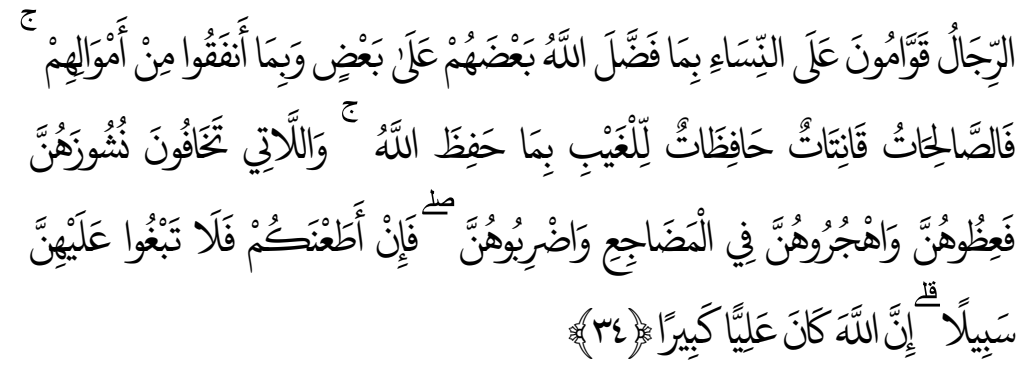

"Kaum laki-laki itu adalah pemimpin bagi kaum wanita, oleh Karena Allah Telah melebihkan sebagian mereka (laki-laki) atas sebagian yang lain (wanita), dan Karena mereka (laki-laki) Telah menafkahkan sebagian dari harta mereka. sebab itu Maka wanita yang saleh, ialah yang taat kepada Allah lagi memelihara diri ketika suaminya tidak ada, oleh Karena Allah Telah memelihara (mereka). wanita-wanita yang kamu khawatirkan nusyuznya, Maka nasehatilah mereka dan pisahkanlah mereka di tempat tidur mereka, dan pukullah mereka. Kemudian jika mereka mentaatimu, Maka janganlah kamu mencari-cari jalan untuk menyusahkannya. Sesungguhnya Allah Maha Tinggi lagi Maha besar."

Kemudian dasar berikutnya adalah hadits Abi Bakrah yang diriwayatkan oleh Bukhari, Ahmad, Nasa'i dan Turmudzi, bahwa Rasulullah SAW bersabda "la yuflihu qaumun wa lau amruhum imratan" (tidak akan berbahagia suatu kaum yang menyerahkan suatu urusan kepada perempuan). Hadits lain menyebutkan bahwa perempuan kurang akal dibandingkan dengan laki-laki. Ketiga dasar tersebut yang kemudian dijadikan dasar alasan larangan perempuan dalam memegang jabatan politik (kepemimpinan). Baik ayat maupun hadits tersebut mengisyaratkan bahwa perempuan tidak pada tempatnya menjadi pemimpin, hanya lakilaki yang pantas menjadi pemimpin dan perempuan wajib mengakui kepemimpinan laki-laki. ${ }^{32}$

\footnotetext{
${ }^{32}$ Bandingkan dengan Said Agil Siradj, Membongkar Citra Perempuan dalam Tasawuf, h. 51-53 dan Said Agil al Munawar, Membongkar Penafsiran Surat al-Nisa ayat 1-4, dalam Syafiq Hasyim (ed), Kepemimpinan Perempuan dalam Islam (Jakarta: P3M, h. 17-18)
} 
Dalam masalah kepemimpinan perempuan, Fatima Mernissi seorang feminis Maroko, melakukan banyak kritik terhadap hadis Nabi yang dinilainya sudah banyak mengalami penyimpangan dan manipulasi. Menurutnya dalam konteks hadits tersebut, Abi Bakrah berada dalam posisi yang sulit, disatu sisi dia harus mendukung Ali bin Abi Thalib sebagai khalifah yang sah, dan disisi lain, kota tempat tinggalnya (Bashrah) dijadikan markas pertahanan dan penghimpunan dari pengikut Aisyah dimana sebagai salah satu pemuka dia haus memilih antara ikut Aisyah atau mendukung Ali. ${ }^{33}$ Selain itu dalam pandangan Mernissi bahwa Abi Bakrah berdasarkan hasil penelitiannya telah memiliki beberapa kelemahan pribadi. ${ }^{34}$

Jika hadits Abi Bakrah menyatakan bahwa tidak akan bahagia suatu kaum yang mengangkat sebagai pemimpin mereka adalah kaum perempuan, maka al-Qur'an justru mengatakan sebaliknya. Al-Qur'an memaparkan kisah seorang ratu yang memimpin kerajaan yang besar yaitu Ratu Balqis, di negeri Saba' ibukota Yaman sekarang. Ratu Balqis dapat memimpin kerajaan Saba' dengan baik dan rakyatnya makmur. ${ }^{35}$ Statement Fatima Mernissi tentang pemimpin perempuan mengatakan bahwa, status pemimpin perempuan dalam Islam memiliki dua pandangan yang saling bertolak belakang, satu sisi menerima sedangkan yang lain menolaknya. Perbedaan ini muncul hanya karena cara pandang yang berbeda dalam menafsirkan teks-teks yang melandasi pemikiran mengenai pemimpin perempuan. Menurut Mernissi memahami pe-

${ }_{33}$ Fatima Mernissi, dalam Charles Kurzman (ed), Wacana Islam Liberal: Pemikiran Islam Kontemporer tentang Isu-isu Global (Jakarta: paramadina, h. 163)

${ }^{34}$ Mernissi melihat dua kelemahan yang ada pada Abi Bakrah, pertama, ABi Bakarah pernah dihukum dan dicambuk oleh khalifah Umar karena memberikan kesaksian palsu pada kasus tuduhan zina terhadap sahabat dan plitikus terkemuka, Mughirah ibn Syu'bah. Kedua, Abi Bakrah dipandang berasal dari keturunan keluarga yang kurang terhormat. Silsilah keluarganya tidak dikenal secara jelas. Lihat: Mernissi, Penafsiran Feminisme tentang Hak-hak Perempuan dalam Islam dalam Charles Kurzman (ed), Wacana Islam Liberal: Pemikiran Islam Kontemporer tentang Isu-isu Global (Jakarta: paramadina, h. 170)

${ }^{35}$ Diceritakan tentang Ratu Balqis dalam al-Qur'an surat al-Naml ayat 23-32. Lihat pula: Fatima Mernissi, Ratu-Ratu Islam yang Terlupakan (terj), (Bandung: Mizan, 1994), h. 218-228. 
mimpin perempuan semestinya dikembalikan kepada prinsip etis agama yang berketaraan dan berkeadilan, karena sejauh pengamatan Mernissi persoalan memimpin bukan semata-mata dilihat dari unsur jenis kelaminnya, apakah itu perempuan atau laki-laki, tetapi tergantung pada kesiapan, kemampuan serta bakat yang dimilikinya, sehingga mampu menjalankan tugasnya dengan baik, adil, jujur dan bijaksana.

Dalam membaca hadits tentang larangan mempimpin bagi perempuan di atas, Hussein Muhammad menilai bahwa hadits tersebut diungkapkan dalam kerangka pemberitahuan, sebuah informasi yang disampaikan Nabi semata dan bukan dalam kerangka legitimasi hukum. Tegasnya hadits tersebut tidak memiliki relevansi hukum. ${ }^{36}$ Selain itu hadits tersebut dilihat dari asbabul wurud-nya, ${ }^{37}$ bersifat kasuistik dan kondisional serta dipahami secara kontekstual.

Meskipun para ahli tafsir ${ }^{38}$ menyatakan bahwa qawwam berarti pemimpin, pelindung, penanggungjawab, pendidik, pengatur dll., yang semakna, dan mereka mengatakan bahwa keunggulan yang dimiliki lakilaki atas perempuan adalah karena keunggulan akal dan fisiknya, namun demikian, dalam memahami surat al-Nisa' ayat 34, menurut Hussein, konteks ayat tersebut menjelaskan kekuasaaan laki-laki atas perempuan dalam lingkup domestik (rumah tangga). Dalam membaca ayat tersebut menurut Hussein harus dipahami sebagai bersifat sosiologis dan kontekstual. ${ }^{39}$ Posisi perempuan yang ditempatkan sebagai subsordinat laki-laki

\footnotetext{
${ }^{36}$ Hussein Muhammad, Figh Perempuan: Refleksi Kyai atas Wacana Agama dan Gender, (Yogyakarta: LKiS, 2011), h. 150.

${ }^{37}$ Asbabrul wurud hadits tersebut adalah bermula dari kisah Abdullah Ibn Hudzaiah, kurir Rasulullah yang menyampaikan surat ajakan masuk Islam kepada Kisra Anusyirwan, penguasa Persia yang beragama Majusi. Ternyata ajakan tersebut dianggap sinis dengan merobek-robek surat. Tidak beberapa lama, firasat itu terjadi, sehingga akhirnya kerajaan dipimpin oleh putrid Kisra yang bernama Buran. Mendengar realitas kepemimpinan negeri Persia yang lemah itu dan secara kondisional itu dipimpin oleh seorang perempuan, maka Nabi bersabda "Tidak akan berbahagia suatu kaum yang menyerahkan suatu urusan kepada perempuan." Lihat: al Ashqalani, Fath al-Barr Syarh al Bukhary, h. 55-56.

${ }^{38}$ Para ahli tafsir yang memiliki pemahaman qawwam adalah pemimpin seperti alRazi, al-Zamakhsyari, al-Thabathaba'i, al-Qurtubi, Ibnu Kasir, Muhanmmad Abduh dan Muhammad Thahir bin Asyur

${ }^{39}$ Hussein Muhammad, Figh Perempuan ..., h. 147.
} 
sesungguhnya muncul dan lahir dari sebuah bangunan masyarakat atau peradaban yang dikuasai laki-laki, yang secara popular dikenal sebagai peradaban patriarki. Artinya ayat al-Qur'an surat al-Nisa' ayat 34 di atas, tidak lain merupakan bentuk atau petunjuk mengenai penerapan kemaslahatan pada situasi dan kondisi riil yang terjadi pada saat ayat itu diturunkan.

Menurut Hussein Muhammad ${ }^{40}$ untuk membaca dan memformulasikan persoalan-persoalan yang terkait dengan relasi antara laki-laki dan perempuan, harus menggunakan kerangka metodologi fikih. Berbagai teks al-Qur'an, hadits, pandangan para ulama, harus dikalsifikasikan ke dalam tiga kerangka, yaitu al-mabadi', al-qawa'id dan al-juz'iyyat. Ada teks-teks ajaran yang masuk dalam tataran fundamental (al-mabadi), ada yang masuk prinsip parsial (al-qawa'id), dan ada yang berada pada tataran norma-norma formal operasional (al-juz'iyyat). Prinisp yang fundamental adalah keadilan dan kemaslahatan untuk semua tanpa membedakan jenis kelamin laki-laki dan perempuan. Keadilan dan kemaslahatan ini merupakan refleksi konklusif dari kesetaraan yang sejak awal diusung oleh al-Qur'an. Beberapa teks yang merupakan klasifikasi al-mabadi' dalam persoalan laki-laki dan perempuan yang secara eksplisit diungkap adalah; pertama, perempuan dan laki-laki diciptakan dari entity (nafs) yang sama (QS. al-Nisa' [4]: 1). Oleh karenanya kedudukan mereka adalah sama dan sejajar yang membedakan hanyalah dari segi kualitas taqwanya (QS. alHujurat [49]: 13). Kedua, perempuan dan laki-laki sama dituntut untuk mewujudkan kehidupan yang baik dengan melakukan kerjasama positif (QS. al-Nahl [16]: 97). Untuk tujuan ini diharapkan perempuan dan lakilaki bahu membahu dan saling membantu dengan yang lain (QS. alTaubah [9]: 71). Ketiga, perempuan dan laki-laki mempunyai hak yang sama untuk memperoleh balasan yang layak atas kerja yang dilakukan (QS. al-Ahzab [33]: 35).

Berdasarkan prinsip al-Mabadi' tersebut menutut Hussein, semua produk hukum dalam masyarakat harus mengacu pada prinsip keadilan

${ }^{40}$ Hussein Muhammad, Kritik Tafsir Gender, dalam Jurnal Yin-Yang, Vol. 1 Nomor 1, PSGA STAIN Purwokerto, Juni 2006. 
dan kesetaraan. Tentang kepemimpinan perempuan (kehadiran perempuan dalam panggung politik), menurut Hussein Muhammad ${ }^{41}$ tidak semata semi kepentingan perempuan melainkan demi keadilan sosial dan kemanusiaan demi mewujudkan keadilan dan kemaslahatan manusia. Lebih lanjut menurut Hussein Muhammad, ${ }^{42}$ hal yang paling esensial dalam kepemimpinan adalah kemampuan dan intelektualitas, dua hal yang dapat dimiliki oleh siapa saja baik laki-laki maupun perempuan.[]

\section{Daftar Pustaka}

Amal, Siti Hidayati, "Beberapa Perspektif Feminis dalam Menganalisa Permasalahan Wanita", dalam T.O. Ihromi (ed.), Kajian Wanita dalam Pembangunan, Jakarta: Yayasan Obor Indonesia, 1995.

Andersen, Margeret L., Thingking About Women: Perspectives on Sex and Gender, New York: McMillan Pub. Co, 1988.

Connel, R.W., Gender and Power Society, The Person and Sexual Politis, Stanford: Standford University Press, 1987.

Enginer, Asghar Ali, Hak-hak Perempuan dalam Islam (diterjemahkan dari The Origin and Developmnet of Islam oleh Farid Wajdi dan Cici Farcha Assegaf), Yogyakarta: Yayasan Banteng Budaya, 1994.

Fakih, Mansour, Analisis Gender dan Transformasi Sosial, Yogyakarta: Pustaka Pelajar, 1996.

Fakih, Mansour (et.al), Membincang Feminisme, Diskursus Gender Perspektif Islam, Surabaya: Risalah Gusti, 1996.

Ilyas, Yunahar, Feminisme dalam Kajian Tafsir al-Qur'an Klasik dan Kontemporer, Yogyakarta: Pustaka Pelajar, 1997.

Ibn Kasir, Abu al Fida' Isma'il bin 'Umar bin Kasir bin Dau', al-Qur'anul Karim, Jil. 1, Beirut: Dar al-Ma'rifat, 1976.

Megawangi, Ratna, "Perkembangan Teori Feminisme Masa Kini dan Mendatang serta Kaitannya dengan Pemikiran Keislaman", dalam Mansour Fakih, dkk., Membincang Feminisme Diskursus Perspektif Islam, Surabaya: Risalah Gusti, 1996.

\footnotetext{
${ }^{41}$ Hussein Muhammad, "Partisipasi Politik Perempuan dalam Perspektif Islam", dalam Jurnal Sawwa, PSGA IAIN Walisongo, Vol. 1 April 2007, h. 29.

${ }^{42}$ Hussein Muhammad, Figh Perempuan..., h. 151.
} 
Mernissi, Fatima dan Rifat Hasan, Setara di Hadapan Allah: Relasi Perempuan dalam Tradisi Islam Pasca Patriarki (terj. Tim LSPPA), Yogyakarta: LSPPA, 1995.

Mernissi, Fatima Mernissi, dalam Charles Kurzman (ed), Wacana Islam Liberal: Pemikiran Islam Kontemporertentang Isu-isu Global, Jakarta: Paramadina. , Ratu-ratu Islam yang Terlupakan (terj), Bandung: Mizan, 1994.

Muhsin, Amina Wadud, Wanita di dalam al-Qur'an, terj. Yaziar Radianti, Bandung: Pustaka, 1994.

Muhammad, Hussein, "Kritik Tafsir Gender", dalam Jurnal Yin-Yang, Vol. 1, No. 1, PSGA STAIN Purwokerto, Juni 2006.

"Partisipasi Politik Perempuan dalam Perspektif Islam", Jurnal Sawwa, PSGA IAIN Walisongo, Vol. 1, April 2007.

, Fiqh Perempuan: Refleksi Kyai atas Wacana Agama dan Gender, Yogyakarta: LKiS, 2011.

Mulia, Siti Musdah, Islam dan Inspirasi Kesetaraan Gender, Yogyakarta: Kibar Press, 2007.

Munawar, Said Agil, "Membongkar Penafsiran Surat al-Nisa' ayat 1-4", dalam Syafiq Hasyim (ed), Kepemimpinan Perempuan dalam Islam Jakarta: P3M.

Mundir, Perempuan dalam al-Qur'an (Studi Tafsir al-Manar), Semarang: Walisongo Press, 2010.

Mutahhari, Murteza, Perempuan dan Hak-haknya dalam Islam, terj. M. Hashem dari The Rights of Women in Islam, Bandung: Pustaka, 1985.

Rahman, Budhy Munawar, "Islam dan Feminisme: Dari Sentralisme kepada Kesetaraan", dalam Mansour Fakih, dkk., Membincang Feminisme, Diskursus Gender PerspektifIslam, Surabaya: Risalah Gusti, 1996.

Rusyd, Ibnu, Fashl al-Maqal fi Taqrir ma baina al-Syari'at wa al-Hikmah min al-Ittishal aw Wujuh al-Nazhar al-'Aqli wa Hudud al-Ta'wil, Beirut: Dirasah al-Wihdah alArabiyah, 1999.

Tuttle, Lisa, Encyclopedia of Feminism, New York: Facts on File Publications, 1986.

Umar, Nasaruddin, Argumen Kesetaraan Gender: Perspektif al-Qur'an. Jakarta: Paramadina, 1999.

Zamakhsyari, Abu al-Qasim Jarullah Mahmud ibn 'Umar, al-Kasysyaf 'an Haqaiq at-Tanzil wa 'Uyun al-Aqailfi Wujuh at-Tanwil, Jili. 1, Beirut: Dar al-Fikr, 1977. 